\title{
Keanekaragaman Serangga Air di Sawah Konvensional dan Organik di Kota Padang
}

\author{
Diversity of Water Insects in Conventional and Organic Rice Cultivations in Padang City \\ Ikhwanul Muslim ${ }^{1)}$, Hasmiandy Hamid ${ }^{2) *}$ dan Martinius ${ }^{2)}$ \\ 1) Program Studi Agroekoteknologi, Fakultas Pertanian, Unand, Padang \\ 2) Program Studi Proteksi Tanaman Fakultas Pertanian Universitas Andalas Padang \\ E-mail: hasmiandyhamid@agr.unand.ac.id
}

\begin{abstract}
Study on diversity of aquatic insects in rice is important to determine the condition of the rice fields. The purpose of this research was to study the community of aquatic insects in two difference cultivations (organic and conventional) and sub districts (Koto Tangah dan Pauh) in Padang City. Purposive random sampling method was used. Samples were collected by using water insect nets and water bottle traps. The results showed that the aquatic insects found in the study site consisted of 5 orders (Coleoptera, Diptera, Ephemeroptera, Hemiptera, Odonata), 16 families, 51 species and 3808 individuals. Aquatic insect populations in organic farming was higher ( 5 orders, 15 families, 48 species and 3089 individuals) than conventional (4 orders, 9 families, 20 species and 719 individuals). Aquatic insects found were acting as predators (3718 individuals), detrivors ( 7 individuals), and omnivors (83 individuals). The diversity indexes of aquatic insects on two locations were classified as medium but the diversity in organic cultivation was higher than conventional.
\end{abstract}

Keywords: Diversity, aquatic insects, conventional and organic rice fields

\section{PENDAHULUAN}

Pemakaian pestisida yang berlebihan dapat menjadi sumber pencemar bagi bahan pangan, air dan lingkungan hidup. Hal ini terjadi karena tidak semua pestisida meng-enai sasaran. Sekitar $80 \%$ pestisida yang diaplikasikan jatuh ke tanah yang dapat mengakibatkan pencemaran lahan per-tanian. Jika masuk ke dalam rantai makanan, maka sifat beracun bahan pestisida dapat menimbulkan berbagai penyakit pada manu-sia seperti kanker, mutasi, bayi lahir cacat, CAIDS (chemically acquired deficiency syndrom) (Sa'id, 1994). Abadi (2005) mengemukakan bahwa penggunaan pes-tisida mengakibatkan terjadinya resistensi pada patogen dan hama, peningkatan popu-lasi hama, bahkan terjadi ledakan hama yang dulunya dianggap tidak penting. Yang lebih penting lagi adalah dampak negatif pestisida terhadap kesehatan manusia dan lingkungan.

Pencemaran pada lahan sawah tidak hanya oleh pestisida saja, tetapi juga oleh pemakain input lain seperti pupuk kimia. Pupuk Nitrogen (N) yang sering digunakan pada lahan sawah untuk memacu pertum-buhan tanaman padi dapat berdampak pada lingkungan, karena $\mathrm{N}$ sangat cepat larut dan tersebar dalam bentuk gas, sehingga akan mencemari sumber daya air dan meningkatkan eutrofikasi (Bellos et al., 2003). Hal tersebut akan mempengaruhi kelimpahan 
organisme air pada lahan sawah. Amonia bersifat racun terhadap organisme air jika dalam kadar yang tinggi, serta dapat mempercepat kegiatan metabolisme organisme air (Sinaga, 2009).

Penggunaan bahan kimia pertanian di negara berkembang mulai dikurangi karena merupakan salah satu penyebab utama pencemaran lingkungan (Ton, 1991). Penerapan sistem pertanian organik me-rupakan jalan yang tepat untuk memper-baiki ekosistem air sawah yang sudah rusak. Keutamaan penggunaan pupuk kompos adalah banyaknya mikroorganisme yang sangat bermanfaat sebagai bioremediasi. Bioremediasi adalah pemanfaatan mikroba sebagai perantara dalam reaksi kimia dan proses fisik secara metabolik di atas permukaan tanah (ex situ) dan di dalam tanah (in situ). Beberapa jenis bakteri, seperti Pseudomonas, Thiobacillus dan bakteri penambat $\mathrm{N}$ dilaporkan mampu mengakumulasi logam berat (Meeting \& Skladany, 1993), sehingga pencemaran air sawah dapat dihilangkan perlahanlahan. Hal ini menguntungkan terhadap serangga air dan organisme lain yang hidup didalamnya.

Penelitian yang dilakukan oleh beberapa peneliti tentang serangga air lebih terfokus kepada pengaruh kualitas air sungai terhadap keanekaragaman serangga air seperti penelitian yang dilakukan Aswari (2001), Thani dan Phalaraks (2008) serta Jupri (2012). Penelitian lain yang dilakukan juga bersifat lebih umum seperti pengaruh kualitas air sungai terhadap keanekaragaman makrozoobenthos seperti yang telah dilakukan Wardhana (1999), Purba (2002), Niswati dan Purnomo (2007), serta Setiawan (2009).

Penelitian tentang serangga air pada lahan sawah konvensional dan organik terutama di Padang belum dilakukan, oleh karena itu penulis telah melakukan penelitian dengan judul
"Keanekaragaman Serangga Air pada Sawah Konvensional dan Organik di Kota Padang". Tujuan penelitian ini adalah untuk mempelajari keanekaragaman serangga air pada lahan sawah konvensional dan organik di Kota Padang.

\section{METODOLOGI}

Penelitian dilaksanakan di Kecamatan Koto Tangah dan Kecamatan Pauh Kota Padang serta di Laboratorium Bioekologi Serangga Fakultas Pertanian Universitas Andalas Padang. Penelitian telah dilaksanakan dari Januari sampai Juli 2013.

\section{Metode}

Penelitian ini dilakukan di lahan sawah konvensional dan organik, sedangkan penentuan lokasi penelitian ini menggunakan metode Purposive Random Sampling. Kriteria yang digunakan dalam penentuan lokasi sampel adalah sistem sawah konvensional dan sawah organik yang masing-masing terdiri dari tiga petakan sawah. Tiap petak sawah memiliki luas $\pm 200 \mathrm{~m}^{2}$. Teknik pengambilan sampel serangga air dilakukan dengan dua cara, yaitu menggunakan botol perangkap dan jaring air.

Berdasarkan kriteria diatas, maka ditetapkan Kecamatan Koto Tangah dan Kecamatan Pauh sebagai lokasi penelitian yang terdiri dari dua lokasi pada tiap kecamatan yaitu sawah konvensional dan sawah organik dengan jarak antara sawah konvensional dan organik $\pm 1 \mathrm{~km}$. Sebelum penetapan sawah konvensional dan organik, terlebih dahulu dilakukan wawancara dengan pemilik lahan. Pertanyaan yang diajukan kepada petani adalah jenis pupuk yang digunakan, jenis pestisida yang digunakan, sumber air untuk sawah organik, tanaman penetralisir yang di pakai pada sawah organik dan mulai sawah organik dirintis. Pengambilan serangga air pada lahan 
sawah konvensional dan organik dilakukan sebanyak dua kali, ketika lahan sawah belum ditanami dan saat tanaman padi dalam fase vegetatif. Sampel serangga air diambil dengan menggunakan botol perangkap dan jaring air. Botol perangkap dibuat dari botol plastik minuman bekas dengan ukuran 1,5 liter sebanyak 15 buah. Botol tersebut dipotong menjadi dua bagian, yaitu sekitar $15 \mathrm{~cm}$ dari ujung bibir botol. Bagian ujung botol yang terdapat lubang kemudian posisinya dibalik dan disorongkan ke dalam bagian botol lainnya. Agar kedua bagian itu terikat kuat, botol diberi selotip. Sebelum diberikan selotip, pada bagian dalam botol diberikan batang cahaya dan ikan kecil sebagai umpan hidup untuk penarik bagi serangga air. Botol perangkap diletakkan pada lima titik secara acak di lahan sawah.

Pengambilan serangga air dengan botol perangkap dilakukan dua kali, yaitu pada pagi dan malam hari. Botol perangkap untuk malam hari dipasang pukul 18.00-07.00 menggunakan cahaya lampu untuk penarik serangga air sedangkan botol perangkap pagi dipasang pukul 07.00-18.00 menggunakan umpan hidup berupa ikan kecil sebagai penarik serangga air.

Pengambilan sampel dengan jaring air dilakukan pada pagi hari, dimulai pada pukul 07.00. Jaring air dimasukkan ke dasar air sawah sampai bibir jaring menyentuh dasar air. Tangkai jaring air dimiringkan sekitar $50^{\circ}$, lalu didorong. Lumpur yang berada dalam jaring air dimasukkan ke air yang mengalir dan digoyangkan pelan-pelan, hal ini dilakukan untuk mengurangi lumpur di dalam jaring air. Serangga air yang didapatkan kemudian dimasukkan ke dalam botol koleksi berisi alkohol $96 \%$ dan diberi label. Pengambilan sampel sebelum tanam dengan menggunakan jaring air dilakukan selama 10 menit dengan mengitari seke- liling sawah sedangkan pengambilan sampel serangga air setelah tanam dilakukan dengan cara mengitari pinggiran sawah. Sampel disortasi dalam nampan putih dan diidentifikasi di laboratorium serta dihitung jumlah populasinya.

Identifikasi dilakukan di Laboratorium Bioekologi Serangga Jurusan Hama dan Penyakit Tumbuhan Fakultas Pertanian Universitas Andalas. Serangga air yang didapatkan di lapangan diidentifikasi sampai tinggkat genus menggunakan kunci identifikasi yang terdapat pada website www.Waterbugkey.vcsu.edu. Penentuan spesies dilakukan berdasarkan perbedaan morfologi (morfo-spesies).

\section{Parameter pengamatan \& analisis data}

Parameter pengamatan berupa kekayaan spesies dan kelimpahan serangga air. Kekayaan spesies dan kelimpahan serangga air diperoleh dengan menghitung jumlah total spesies dan jumlah individu serangga air yang dikoleksi pada masingmasing lokasi penelitian.

Keanekaragaman serangga air dapat diukur dengan menggunakan indeks keanekaragaman Shannon-Wienner (Krebs, 1999) sebagai berikut:

$$
\begin{aligned}
& \mathrm{H}^{\prime}=-\sum p i \ln p i \\
& \mathrm{Pi}=\mathrm{n} / \mathrm{N}
\end{aligned}
$$

Keterangan :

$\mathrm{H}^{\prime}=$ Indeks keanekaragaman ShannonWienner

$\mathrm{Pi}=$ Proporsi individu spesies ke-i pada komunitas

In = Logaritma nature

$\mathrm{n}=$ Kelimpahan individu spesies ke-i

$\mathrm{N}=$ Jumlah total individu semua spesies

Kemerataan spesies adalah proporsi masing-masing spesies dalam suatu komunitas. Kemerataan spesies dapat dihitung menggunakan indeks kemerataan Shannon-Wienner (Krebs, 1999) sebagai berikut:

$$
\mathrm{E}=\mathrm{H}^{\prime} / \ln \mathrm{S}
$$

Keterangan : 
Muslim et al. Keanekaragaman Serangga Air di Sawah

$\mathrm{E}=$ Indeks kemerataan spesies

$$
\mathrm{S}=\text { Jumlah spesies }
$$

$\mathrm{H}^{\prime}=$ Indeks Shannon-Wienner

Tabel 1. Kriteria indeks Shannon-Wienner

\begin{tabular}{|c|c|c|c|}
\hline $\begin{array}{c}\text { Indeks keanekaragaman } \\
\left(\mathrm{H}^{\prime}\right)\end{array}$ & Kondisi struktur komunitas & Kategori & Skala \\
\hline$>2,41$ & Sangat Stabil & Sangat Baik & 5 \\
\hline$<2,41$ & Lebih Stabil & Baik & 4 \\
\hline $1,21-1,8$ & Stabil & Sedang & 3 \\
\hline $0,61-1,2$ & Cukup Stabil & Buruk & 2 \\
\hline$<0,6$ & Tidak Stabil & Sangat Buruk & 1 \\
\hline Indeks Kemerataan (E) & $\begin{array}{c}\text { Kondisi penyebaran jenis } \\
\text { struktur komunitas }\end{array}$ & Kategori & Skala \\
\hline$>0,81$ & Sangat Stabil & Sangat Baik & 5 \\
\hline $0,61-0,80$ & Lebih Stabil & Baik & 4 \\
\hline $0,41-0,60$ & Stabil & Sedang & 3 \\
\hline $0,21-0,40$ & Cukup Stabil & Buruk & 2 \\
\hline$<0,20$ & Tidak Stabil & Sangat Buruk & 1 \\
\hline
\end{tabular}

(Sumber : Krebs, 1999)

HASIL

\section{Deskripsi lokasi}

Penelitian dilakukan di dua tempat berbeda yaitu di Kecamatan Koto Tangah dan Kecamatan Pauh dan dengan dua sistem budidaya berbeda yaitu konvensional dan organik. Perbedaan dan persamaan kedua-nya disajikan pada Tabel 2.

Tabel 2. Deskripsi lokasi penelitian di dua kecamatan dan dua sistem budidaya berbeda

\begin{tabular}{|c|c|c|c|}
\hline \multirow{2}{*}{ Kecamatan } & \multirow{2}{*}{$\begin{array}{c}\text { Parameter } \\
\text { pengamatan }\end{array}$} & \multicolumn{2}{|r|}{ Sistem pertanian } \\
\hline & & Konvensional & Organik \\
\hline \multirow{5}{*}{ Koto Tangah } & Pupuk & $\begin{array}{l}\text { Urea, Phonska, } \\
\text { SP } 36\end{array}$ & $\begin{array}{l}\text { Pupuk kompos dari campuran kotoran sapi, } \\
\text { jerami, batang pisang, Tithonia dan } \\
\text { Trichoderma }\end{array}$ \\
\hline & Pestisida & $\begin{array}{l}\text { Curater, Dursban, } \\
\text { Record, Regent }\end{array}$ & $\begin{array}{l}\text { Pestisida nabati dari daun Toona sinensis, } \\
\text { daun Cymbopogon citratus. Entomopatogen } \\
\text { Beauveria }\end{array}$ \\
\hline & Sumber air & $\begin{array}{l}\text { Dari aliran sawah } \\
\text { sekitar }\end{array}$ & Irigasi sawah \\
\hline & $\begin{array}{l}\text { Tanaman penetralisir } \\
\text { air }\end{array}$ & - & Eichhornia crassipes \\
\hline & $\begin{array}{l}\text { Mulainya sawah } \\
\text { organik dirintis }\end{array}$ & - & 2005 \\
\hline \multirow{4}{*}{ Pauh } & Pupuk & $\begin{array}{l}\text { Urea, Phonska, } \\
\text { SP 36, Organik Butiran }\end{array}$ & $\begin{array}{l}\text { Pupuk kompos dengan campuran kotoran } \\
\text { sapi, jerami dan Trichoderma }\end{array}$ \\
\hline & Pestisida & \multicolumn{2}{|c|}{$\begin{array}{l}\text { Sidacin, Curater, RegentPestisida nabati dari daun Toona sinensis, } \\
\qquad \begin{array}{l}\text { daun Mentha arvensis, daun Cassia alata, } \\
\text { daun Annona muricata. Entomopatogen } \\
\text { Beauveria }\end{array}\end{array}$} \\
\hline & Sumber air & $\begin{array}{l}\text { Dari aliran sawah } \\
\text { sekitar }\end{array}$ & Irigasi sawah \\
\hline & $\begin{array}{l}\text { Tanaman penetralisir } \\
\text { air }\end{array}$ & - & Eichhornia crassipes \\
\hline
\end{tabular}


Muslim et al. Keanekaragaman Serangga Air di Sawah

Mulainya sawah _ _ 2009

organik dirintis

\section{Jumlah individu serangga air}

Serangga air yang ditemukan adalah 3.918 individu yang tersebar dalam 5 ord dan 16 family. Serangga air Koto Tangah lebih banyak dibandingkan Pauh, dan serangga air di sistem budidaya organik lebih banyak dibandingkan konvensional. Pada sistem budidaya konvensional di Koto Tangah ditemukan serangga air sebanyak 375 individu, 16 spesies dan pada sistem sawah organik ditemukan sebanyak 2.128 individu, 44 spesies, sedangkan di Pauh ditemukan 344 individu, 9 spesies pada sistem sawah konvensional dan 961 individu, 34 spesies ditemukan pada sistem sawah organik. Individu serangga yang paling banyak ditemukan adalah Corixidae (Hemiptera), sedangkan jumlah spesies yang paling banyak ditemukan adalah Libellulidae (Odonata) (Tabel 3).

Tabel 3. Jenis dan jumlah individu serangga air dengan perbedaan lokasi (Kecamatan Koto Tangah dan Kecamatan Pauh) dan sistem budidaya (konvensional dan Organik)

\begin{tabular}{|c|c|c|c|c|c|c|c|c|c|}
\hline \multirow{3}{*}{ Ordo } & \multirow{3}{*}{ Famili } & \multicolumn{4}{|c|}{ Koto Tangah } & \multicolumn{4}{|c|}{ Pauh } \\
\hline & & \multicolumn{2}{|c|}{ Konvensional } & \multicolumn{2}{|c|}{ Organik } & \multicolumn{2}{|c|}{ Konvensional } & \multicolumn{2}{|c|}{ Organik } \\
\hline & & JS & $\mathrm{J}$ & JS & $\mathrm{J}$ & $\mathrm{JS}$ & $\mathrm{J}$ & JS & J \\
\hline \multirow{5}{*}{ Coleoptera } & Chrysomelidae & 0 & 0 & 1 & 1 & 0 & 0 & 0 & 0 \\
\hline & Dytiscidae & 2 & 2 & 12 & 74 & 4 & 13 & 9 & 39 \\
\hline & Hydraenidae & 0 & 0 & 1 & 5 & 0 & 0 & 1 & 1 \\
\hline & Hydrophilidae & 3 & 5 & 3 & 6 & 1 & 2 & 3 & 46 \\
\hline & Jumlah & 5 & 7 & 17 & 86 & 5 & 15 & 13 & 86 \\
\hline \multirow{3}{*}{ Diptera } & Chironomidae & 0 & 0 & 2 & 50 & 0 & 0 & 1 & 16 \\
\hline & Culicidae & 1 & 4 & 1 & 4 & 0 & 0 & 1 & 6 \\
\hline & Jumlah & 1 & 4 & 3 & 54 & 0 & 0 & 2 & 22 \\
\hline \multirow{5}{*}{ Ephemeroptera } & Baetidae & 0 & 0 & 1 & 1 & 0 & 0 & 1 & 1 \\
\hline & Leptophlebiidae & 0 & 0 & 0 & 0 & 0 & 0 & 1 & 1 \\
\hline & Jumlah & 0 & 0 & 1 & 1 & 0 & 0 & 2 & 2 \\
\hline & Corixidae & 1 & 166 & 2 & 1.188 & 1 & 172 & 2 & 547 \\
\hline & Gerridae & 0 & 0 & 1 & 2 & 1 & 5 & 1 & 8 \\
\hline \multirow[t]{5}{*}{ Hemiptera } & Hydrometridae & 0 & 0 & 1 & 4 & 0 & 0 & 0 & 0 \\
\hline & Naucoridae & 1 & 1 & 0 & 0 & 0 & 0 & 0 & 0 \\
\hline & Notonectidae & 1 & 177 & 1 & 678 & 1 & 150 & 1 & 244 \\
\hline & Jumlah & 3 & 344 & 5 & 1.872 & 3 & 327 & 4 & 799 \\
\hline & Aeshnidae & 0 & 0 & 1 & 1 & 0 & 0 & 0 & 0 \\
\hline \multirow[t]{4}{*}{ Odonata } & Coenagrionidae & 1 & 1 & 6 & 50 & 0 & 0 & 4 & 18 \\
\hline & Libellulidae & 6 & 19 & 11 & 64 & 1 & 2 & 9 & 41 \\
\hline & Jumlah & 7 & 20 & 18 & 115 & 1 & 2 & 13 & 59 \\
\hline & Total & 16 & 375 & 44 & 2.128 & 9 & 344 & 34 & 968 \\
\hline
\end{tabular}

Keterangan: JS = Jumlah Spesies; JI = Jumlah Individu

Jumlah individu serangga air berdasarkan perannya

Peran serangga air yang ditemukan bervariasi, yaitu sebagai predator, detrivor dan omnivor. Pada sistem sawah konvensional ditemukan serangga air yang bersifat predator sebanyak 715 individu, serangga air bersifat detrivor tidak 
ditemukan, bersifat omnivor 4 individu, omnivor sebanyak 79 individu. Hasil sedangkan pada sistem sawah organik selengkapnya dapat dilihat pada Tabel 4 dan ditemukan serangga air bersifat predator Tabel 5 .

3.003 individu, detrivor 7 individu dan

Tabel 4. Jenis dan jumlah individu serangga air berdasarkan perannya

\begin{tabular}{|c|c|c|c|c|c|c|c|c|}
\hline \multirow{3}{*}{ Ordo } & \multirow{3}{*}{ Famili } & \multirow{3}{*}{ Jumlah spesies } & \multicolumn{6}{|c|}{ Jumlah individu } \\
\hline & & & \multicolumn{2}{|c|}{ Predator } & \multicolumn{2}{|c|}{ Detrivor } & \multicolumn{2}{|c|}{ Omnivor } \\
\hline & & & S.K & S.O & S.K & S.O & S.K & S.O \\
\hline \multirow{4}{*}{ Coleoptera } & Chrysomelidae & 1 & 0 & 0 & 0 & 1 & 0 & 0 \\
\hline & Dytiscidae & 13 & 15 & 113 & 0 & 0 & 0 & 0 \\
\hline & Hydraenidae & 1 & 0 & 0 & 0 & 6 & 0 & 0 \\
\hline & Hydrophilidae & 6 & 7 & 52 & 0 & 0 & 0 & 0 \\
\hline \multirow{2}{*}{ Diptera } & Chironomidae & 2 & 0 & 0 & 0 & 0 & 0 & 66 \\
\hline & Culicidae & 1 & 0 & 0 & 0 & 0 & 4 & 10 \\
\hline \multirow{2}{*}{ Ephemeroptera } & Baetidae & 1 & 0 & 0 & 0 & 0 & 0 & 2 \\
\hline & Leptophlebiidae & 1 & 0 & 0 & 0 & 0 & 0 & 1 \\
\hline \multirow{5}{*}{ Hemiptera } & Corixidae & 2 & 338 & 1735 & 0 & 0 & 0 & 0 \\
\hline & Gerridae & 1 & 5 & 10 & 0 & 0 & 0 & 0 \\
\hline & Hydrometridae & 1 & 0 & 4 & 0 & 0 & 0 & 0 \\
\hline & Naucoridae & 1 & 1 & 0 & 0 & 0 & 0 & 0 \\
\hline & Notonectidae & 1 & 327 & 922 & 0 & 0 & 0 & 0 \\
\hline \multirow{3}{*}{ Odonata } & Aeshnidae & 1 & 0 & 1 & 0 & 0 & 0 & 0 \\
\hline & Coenagrionidae & 7 & 1 & 61 & 0 & 0 & 0 & 0 \\
\hline & Libellulidae & 11 & 21 & 105 & 0 & 0 & 0 & 0 \\
\hline
\end{tabular}

Keterangan: S.K = Sawah Konvensional; S.O = Sawah Organik

Tabel 5. Ordo dan jumlah indvidu serangga air berdasarkan perannya

\begin{tabular}{lrrrrrr}
\hline \multirow{2}{*}{ Ordo } & \multicolumn{2}{c}{ Predator } & \multicolumn{2}{c}{ Detrivor } & \multicolumn{2}{c}{ Omnivor } \\
\cline { 2 - 7 } & Konvensional & Organik & Konvensional & Organik & Konvensional Organik \\
\hline Coleoptera & 22 & 165 & 0 & 7 & 0 & 0 \\
Diptera & 0 & 0 & 0 & 0 & 4 & 76 \\
Ephemeroptera & 0 & 0 & 0 & 0 & 0 & 3 \\
Hemiptera & 671 & 2.671 & 0 & 0 & 0 & 0 \\
Odonata & 22 & 167 & 0 & 0 & 0 & 0 \\
\hline \multicolumn{1}{c}{ TOTAL } & $\mathbf{7 1 5}$ & $\mathbf{3 . 0 0 3}$ & $\mathbf{0}$ & $\mathbf{7}$ & $\mathbf{4}$ & $\mathbf{7 9}$ \\
\hline
\end{tabular}

\section{Keanekaragaman}

Kekayaan spesies, kelimpahan individu, indeks keanekaragaman dan kemerataan serangga air lebih tinggi pada budidaya organik dari pada konvensional, begitu juga halnya dengan kekayaan

Tabel 6. Kekayaan spesies, kelimpahan individu, indeks keanekaragaman dan kemerataan serangga air pada beberapa lokasi penelitian

Parameter

Kec. Koto Tangah Konvensional spesies dan kelimpahan individu serangga air di Koto Tangah lebih tinggi dibandingkan Pauh. Indeks keanekaragaman dan kemerataan spesies di kedua lokasi tergolong sedang (Tabel 6).

\begin{tabular}{ccccc}
\multicolumn{2}{c}{ serangga air pada beberapa lokasi penelitian } \\
\cline { 2 - 4 } Parameter & \multicolumn{2}{c}{ Kec. Koto Tangah } & \multicolumn{2}{c}{ Kec. Pauh } \\
\cline { 2 - 4 } & Konvensional & Organik & Konvensional Organik \\
\hline
\end{tabular}


Muslim et al. Keanekaragaman Serangga Air di Sawah

\begin{tabular}{lcccc}
\hline Jumlah spesies & 16 & 44 & 9 & 34 \\
Jumlah Individu & 375 & 2128 & 344 & 961 \\
Keanekaragamanspesies $\left(\mathrm{H}^{\prime}\right)$ & 1,13 & 1,43 & 0,99 & 1,55 \\
Kemerataan spesies $(\mathrm{E})$ & 0,58 & 0,60 & 0,56 & 0,62 \\
\hline
\end{tabular}

\section{PEMBAHASAN}

Dari penelitian ini ditemukan 5 ordo serangga air (Coleoptera, Diptera, Ephemeroptera, Hemiptera, Odonata) yang tersebar dalam 16 famili. Serangga air dari ordo lain, seperti Plecoptera, Trichoptera dan ordo lain tidak ditemukan, kemungkinan besar serangga air dari ordo lain tersebut habitatnya bukan di sawah tapi pada aliran sungai atau danau. McCafferty (1981) mengemukakan bahwa kurang lebih $10 \%$ serangga menempati habitat perairan yang berasal dari ordo Ephemeroptera, Odonata, Plecoptera, Trichoptera, Coleoptera, Lepidoptera, Hymenoptera, Hemiptera, Diptera, Megaloptera, Neuroptera, Orthoptera, dan Collembola. Semua ordo ini menempati habitat yang bervariasi mulai dari kolam, sungai dan danau yang meliputi baik ekosistem lentik dan ekosistem lotik merupakan tempat hidup dan berkembang bagi serangga air.

Famili yang dominan ditemukan pada sawah konvensional dan organik adalah famili Corixidae dan Notonectidae dari ordo Hemiptera. Kedua famili dari ordo Hemiptera ini bersifat sebagai predator. Famili Corixidae dan Notonectidae sama-sama memangsa larva dan binatang air yang kecil (VCSU, 2013). Faktor penyebab melimpahnya jumlah individu kedua famili tersebut diduga keduanya mempunyai kemampuan reproduksi yang tinggi, ditambah lagi banyaknya sumber makanan yang tersedia di dalam air yang membantu mempercepat proses reproduksi. Tarumingkeng (1994) menyatakan bahwa tinggi rendahnya tingkat reproduksi suatu spesies akan menentukan juga tinggi atau rendahnya jumlah individu spesies tersebut dalam suatu populasi. Kedua famili dari ordo Hemiptera ini kemungkinan juga memiliki kemampuan genetik yang sangat bagus dalam beradaptasi terhadap perubahan yang terjadi pada lingkungan habitatnya. Variasi genetik dalam suatu populasi diperlukan untuk berevolusi dan adaptasi, apabila variasi genetik dalam suatu populasi tinggi, maka kemampuan beberapa individu dalam populasi tersebut untuk beradaptasi terhadap perubahanperubahan lingkungan semakin tinggi, sehingga kedua famili ini mampu berkembangbiak pada sawah konvensional.

Ordo serangga air yang banyak ditemukan selain ordo Hemiptera adalah ordo Coleoptera, sedangkan ordo yang jumlah individunya lebih sedikit ditemukan adalah ordo Diptera dan Ephemeroptera. Hal ini disebabkan oleh faktor ekologi serangga itu sendiri, seperti famili Chironomidae dan famili Baetidae kemampuan mereka yang pasif bergerak serta hidup di dasar air pada lumpur yang bercampur serasah (Frouz, 2003) sehingga hanya bisa ditangkap menggunakan jaring air saja. Tubuh famili ini lunak dan kecil, mereka mudah rusak bahkan lenyap oleh beratnya lumpur di lapangan, sehingga jumlah individu famili ini sedikit didapatkan.

Jumlah serangga air pada sistem sawah organik lebih tinggi dari sistem sawah konvensional. Pada sistem sawah organik jumlah ordo, famili, spesies dan individu serangga air lebih tinggi dibandingkan sistem sawah konvensional (Tabel 3). Hal ini disebabkan pada sistem sawah organik tidak menggunakan pupuk kimia dan pestisida sintetik dalam budidaya tanaman padi. Pertanian organik meman- 
faatkan semua bahan alami yang ada di alam sehingga tidak berbahaya bagi kehidupan makhluk hidup pada ekosistem tanaman padi terutama serangga air yang berada di dalam genangan air sawah. Berbeda jauh dengan sistem sawah konvensional, budidaya tanaman padi selalu menggunakan pupuk kimia dan pestisida sintetik sehingga mengurangi keanekaragaman serangga air didalamnya. Effendi (2003) mengemukakan bahwa air yang telah tercemar oleh bahan buangan yang bersifat antiseptik atau bersifat racun, seperti fenol, kreolin, detergen, asam cianida, insektisida dan sebagainya, jumlah organismenya juga relatif sedikit. Keberadaan logam berat yang berlebihan di perairan akan mempengaruhi sistem respirasi organisme akuatik, sehingga pada saat kadar oksigen terlarut rendah dan terdapat logam berat dengan konsentrasi tinggi membuat kehidupan organisme akuatik menjadi terganggu (Tebbut, 1992 cit Effendi, 2003). Lina (2004) juga menyatakan bahwa semakin banyak zat pencemar pada air akan menyebabkan menurunnya kadar oksigen terlarut dalam air tersebut, sehingga akan mengakibatkan kehidupan dalam air yang membutuhkan oksigen terganggu serta mengurangi perkembangannya.

Kualitas air pada sawah oganik lebih bagus dibandingkan sawah konvensional. Hal ini dilihat dari hasil pengamatan dimana ditemukannya serangga air dari ordo Ephemeroptera yang tidak ditemukan pada sawah konvensional. Ada tiga taksa sensitif biasa digunakan untuk menilai kualitas perairan terdiri dari ordo Ephemeroptera, Plecoptera, dan Tricoptera yang dikenal dengan kelompok EPT (Gooderham, 1998 cit Mahajoeno, Efendi \& Ardiansyah, 2001). Penemuan ordo Ephemeroptera pada sawah organik menunjukkan bahwa air genangan pada sawah organik tidak tercemar oleh zat kimia berbahaya. Samways (1994) menyatakan bahwa jika keberadaan serangga Ephemeroptera tidak ada di dalam sebuah perairan menandakan lingkungan tersebut telah tercemar, karena serangga ini tidak dapat hidup pada habitat yang sudah tercemar.

Jumlah serangga air pada sistem sawah organik lebih banyak ditemukan di Kec. Koto Tangah dibandingkan Kec. Pauh. Keadaan ini diduga pada penerapan sawah organik di Kec. Koto Tangah telah lama dilakukan dibandingkan sistem sawah organik di Kec. Pauh. Sistem sawah organik di Kec. Koto Tangah sudah dirintis sejak tahun 2005 sampai sekarang, sedangkan sistem sawah organik di Kec. Pauh dimulai pada tahun 2009 sampai sekarang. Lamanya pemakaian pupuk kompos dan ditambah lagi dengan pelapukan jerami yang dibenamkan ke dalam sawah tentu akan berpengaruh terhadap struktur tanah dan suhu didalam air sawah yang nantinya juga akan berpengaruh terhadap keanekaragaman serangga air yang hidup didalamnya. Salmah (1999) menyatakan bahwa komunitas serangga juga mencerminkan tingkat dan struktur habitatnya.

Serangga air yang banyak ditemukan bersifat sebagai predator (Tabel 6). Oleh karena itu, pemanfaatan serangga air ini sangat bagus untuk pengendalian hama dan penyakit pada tanaman padi, seperti spesies Limnogonus fossarum yang memakan hama wereng, ngengat ataupun larva yang jatuh ke permukaan dan imago dari ordo Odonata yang aktif mampu memakan hama wereng hijau, ngengat penggerek batang padi dan jenis ngengat lainnya yang menyebabkan kerusakan dan penyakit pada tanaman padi. Serangga air yang bersifat detrivor hanya memakan serasah, sehingga tidak bersifat sebagai hama bagi tanaman padi dan yang bersifat omnivor memakan serasah tanaman yang 
Muslim et al. Keanekaragaman Serangga Air di Sawah

sudah mati dan mikrorganisme yang ada di dalam air (VCSU, 2013).

Indeks keanekaragaman dan kemerataan pada sawah organik lebih tinggi dibandingkan sawah konvensional. Pemakai-an pupuk kimia dan pestisida membuat ekosistem pada sawah konvensional menjadi rusak. Krebs (1999) menyatakan bahwa semakin rendah nilai indeks keaneka-ragaman maka semakin menurun tingkat keteraturan dan kestabilan pada suatu ekosistem. Secara keseluruhan nilai indeks keanekaragaman pada sawah organik dikedua Kecamatan (Tabel 8) termasuk dalam kategori sedang (Tabel 1), sedangkan indeks keanekaragaman spesies pada sawah konvensional di kedua Kecamatan (Tabel 8) berada pada kategori buruk (Tabel 1). Hal ini dapat disimpulkan bahwa indeks $\mathrm{H}^{\prime}$ pada sawah organik belum termasuk kategori baik, tetapi dalam ketegori cukup baik. Diduga masih ada faktor-faktor yang mempengaruhi baik dalam teknik pengambilan sampel maupun lingkungan sekitar sawah organik yang masih memakai sistem sawah konvensional. Hugnes (1978) menyatakan, selain metode dan teknik pengambilan sampel, kedalaman pengambil-an sampel, ukuran sampel, lamanya pengambilan sampel sangat berpengaruh terhadap jenis yang ditemukan. Indeks kemerataan pada sawah organik di Kecamatan Pauh termasuk kategori baik (Tabel 1) yaitu > 0,61, sedangkan pada lokasi lain baik di Kecamatan Koto Tangah termasuk kategori sedang (Tabel 1) yaitu berkisar antara 0,56-0,60. Menurut Krebs (1999) nilai indeks kemerataan berkisar antara 0-1, jika nilai mendekati 0 berarti keme-rataan rendah karena ada jenis yang mendominasi. Bila nilai mendekati satu maka kemerataan tinggi dan meng-gambarkan tidak ada jenis yang mendominasi sehingga pembagian jumlah individu pada masing-masing jenis sangat seragam atau merata.

\section{KESIMPULAN}

Serangga air yang ditemukan di lokasi penelitian terdiri dari 5 ordo (Coleoptera, Diptera, Ephemeroptera, Hemiptera, Odonata), 16 famili, 51 spesies dan 3.808 individu. Populasi serangga air pada budidaya organik lebih tinggi (5 ordo, 15 famili, 48 spesies dan 3089 individu) dibandingkan sistem sawah konvensional (4 ordo, 9 famili, 20 spesies dan 719 individu). Serangga air yang ditemukan bersifat sebagai predator (3.718 individu), detrivor ( 7 individu), omnivor (83 individu). Keaneka-ragaman dan kemerataan serangga air di kedua lokasi tergolong sedang.

\section{DAFTAR PUSTAKA}

Abadi AL. 2005. Permasalahan dalam penerapan sistem pengendalian hama terpadu untuk pengelolaan penyakit tumbuhan di Indonesia. Pidato Pengukuhan Guru Besar dalam Ilmu Penyakit Tumbuhan Pada Fakultas Pertanian Universitas Brawijaya.

Aswari P. 2001. Keragaman serangga air di Taman Nasional Gunung Halimun. Pusat Penelitian Biologi. LIPI.

Bellos D, T Sawidis dan I Tsekos. 2003. Nutrient chemistry of River Pinios (Thessalia, Greece). Environment International 30:105-115.

Effendi. 2003. Telaah kualitas air bagi pengelolaan sumber daya dan lingkungan perairan. Penerbit Kanisius. Yogyakarta.

Frouz J, J Matena dan Ali. 2003. Survival strategies of Chironomids (Diptera: Chironomidae) living in temporary habitat: a Review. European Journal of Entomology 100: 459-465.

Hugnes BD. 1978. The Influence of factor other that pollution on the value of Shannon Diversity Index of bentic 
macroinvertebrates in stream. Water Research. Pargamon Press. Cardiff.

Jupri. 2012. Keanekaragaman serangga air di daerah aliran sungai Dendang Ketereh Kota Bharu Kelantan Malaysia. Universitas Andalas. Padang.

Krebs CJ. 1999. Ecological metodology. Second Edition. An Imprint of Addition Wesley Longmen, Inc. New York.

Lina W. 2004. Pencemaran air: Sumber, dampak dan penanggulangannya. Institut Pertanian Bogor. Bogor.

Mahajoeno E, M Efendi dan Ardiansyah. 2001. Keanekaragaman larva insekta pada sungai-sungai Kecil di hutan Jobolarangan. Jurnal Biodiversitas. http:// biodiver-sitas.mipa.uns.ac.id /D/ D0202/ D0202 pdf / D020202.pdf

McCafferty WP. 1981. Aquatic entomology. The fishemen's and ecologist illustrated guide to insect and their relatives. Jones and Bartlett Publishers, Inc.Boston.

Meeting FBJ dan GF Skladany. 1993. Bioremediation of contaminated soil. In F.B. Meeting (Ed). Soil microbial ecology: Aplications in agricultural and environmental management, Marcel Dekker. Inc. New York.

Niswati A dan Purnomo. 2007. Perubahan komunitas dan keanekaragaman organisme air genangan tanah sawah pada tanah sawah pagelaran dan Taman Bogor Provinsi Lampung. Univesitas Lampung. Lampung.

Purba IR. 2002. Pengaruh kegiatan pertanian dan pemukiman terhadap kualitas air dan keanekaragaman mikrozoo-benthos (Studi Kasus Kecamatan Purba Kabupaten Simalungun. Thesis. USU. Medan.
Sa'id EG. 1994. Dampak negatif pestisida, Sebuah catatan bagi kita semua. Agrotek 2(1): 71-72.

Salmah CRM. 1999. Macroinvertebrates of Kedah and Pinang Rivers. School of Biologycal Scince, University Sains Malaysia.

Samways MJ. 1994. Insect conservation biology. Chapman \& Hall. New York.

Setiawan D. 2009. Studi komunitas makrozoobenthos di perairan hilir Sungai Lematang sekitar daerah pasar bawah Kabupaten Lahat. Universitas Sriwijaya. Sumatera Selatan.

Sinaga T. 2009. Keanekaragaman makrozoobentos sebagai indikator kualitas perairan Danau Toba balige Kabupaten Toba Samosir [Tesis]. Medan. Sekolah Pascasarjana Universitas Sumatra Utara.

Thani I dan C Phalaraksh. 2008. A preliminary study of aquatic diversity and water quality of Mekong River. Thailand.

Tarumingkeng RC. 1994. Dinamika populasi. Insitut Pertanian Bogor. Artikel Online. http:/tumouto.net/dinamikapopul.html. [17 Januari 2014]

Ton SW. 1991. Environmental considerations with use of pesticides in agriculture. Paper pada Lustrum ke-VIII Fakultas Pertanian USU, Medan.

VCSU. 2013. Digital key to aquatic insects of North Dakota. www.waterbugkey.vcsu.edun /index.htm [17 Oktober 2013]

Wardhana W. 1999. Perubahan lingkungan perairan dan pengaruhnya terhadap biota a kuatik. Jurusan Biologi FMIPA-UI. Depok. 
Muslim et al. Keanekaragaman Serangga Air di Sawah 